\title{
Pendeteksian Susut Daya Pelanggan dalam Upaya Meningkatkan Efisiensi Penggunaan Energi
}

\author{
Yessy Asri ${ }^{1}$; Dwina Kuswardani ${ }^{2}$; Efy Yosrita ${ }^{3}$; Ferdinand Hendrik Wullur ${ }^{4}$ \\ 1, 2, 3, 4Jurusan Teknik Informatika, Institut Teknologi PLN, Jakarta, Indonesia \\ ${ }^{1}$ yessyasri@itpln.ac.id \\ 22dwina@itpln.ac.id \\ 3efyyosrita@itpln.ac.id \\ 4ferdinand141314@sttpln.ac.id
}

\begin{abstract}
Automatic Meter Reading (AMR) is a reading system or taking data result the measurement of electrical energy on consumen, both locally and remotely. One of the functions of this system is to calculate losses or shrinkage of distribution. One of the problems faced by PLN is the high nontechnical shrinkage of potential AMR customers due to installation and maintenance errors as well as dishonest actions taken by some consumers, this has a major influence on electrical power losses. Clustering that can be used to facilitate the analysis and evaluation of data is needed to ease the workload. The K-Means method is used in this study to cluster data based on historical electric power usage and to determine the most optimal number of groups the Davies-Bouldin Index (DBI) method is used. Based on the results of testing with 2-6 sets of clusters, the cluster set results are the most optimal is set cluster 4 because it has the smallest DBI value, that is, 0.893, that means set cluster 4 has the density of each object with the best centroid and the distance between the clusters is also well separated. Cluster 1 has 12 members, cluster 2: 54 members, cluster 3: 34 members and cluster 4:3 members. It is expected that this system can be used by officers employees in the Distribution sector, Sub sector Efficiency, Measurement and Quality of the Distribution System for setting P2TL operating targets at the distribution office of PT. PLN (Pesero) Distribution of Jakarta Raya.
\end{abstract}

Keywords: AMR (Automatic Meter Reading), K-Means, Davies-Bouldin Index (DBI), Power Loss

\begin{abstract}
ABSTRAK
Automatic Meter Reading (AMR) adalah sistem pembacaan atau pengambilan data hasil pengukuran energi listrik pada konsumen, baik secara lokal maupun jarak jauh. Salah satu fungsi sistem ini adalah untuk menghitung kerugian atau penyusutan distribusi. Salah satu masalah yang dihadapi oleh PLN adalah penyusutan non-teknis yang tinggi dari pelanggan AMR potensial karena kesalahan pemasangan dan pemeliharaan serta tindakan tidak jujur yang dilakukan oleh beberapa konsumen, ini memiliki pengaruh besar pada kerugian daya listrik. Pengelompokan yang dapat digunakan untuk memfasilitasi analisis dan evaluasi data dibutuhkan untuk memudahkan pekerjaan. Metode K-Means digunakan dalam penelitian ini untuk mengelompokkan data berdasarkan riwayat penggunaan daya listrik dan untuk menentukan jumlah kelompok yang paling optimal digunakan metode Davies-Bouldin Index (DBI). Berdasarkan hasil pengujian dengan 2-6 set cluster, hasil set cluster yang paling optimal adalah set cluster 4 karena memiliki nilai DBI terkecil, yaitu 0,893, yang berarti set cluster 4 memiliki kepadatan masing-masing objek dengan centroid terbaik dan jarak antar cluster juga dipisahkan dengan baik. Cluster 1 memiliki 12 anggota, klaster 2: 54 anggota, klaster 3: 34 anggota dan klaster 4: 3 anggota. Diharapkan bahwa sistem ini dapat digunakan oleh petugas karyawan di sektor Distribusi, Efisiensi, Pengukuran dan Kualitas Sub Sistem Sistem Distribusi untuk menetapkan target operasi P2TL di kantor distribusi PT. PLN (Pesero) Distribusi Jakarta Raya.
\end{abstract}

Kata kunci: AMR (Automatic Meter Reading), K-Means, Davies-Bouldin Index (DBI), Susut Daya 


\section{PENDAHULUAN}

Kerugian atau kehilangan daya listrik dalam sistem distribusi tenaga listrik yang biasanya digunakan pada waktu-waktu tertentu, adalah salah satu ukuran yang efisien atau tidak operasi sistem tenaga listrik [1] [2] [3] [10] [12] [19].

Saat ini telah diterapkan metode pengukuran energi listrik menggunakan sistem AMR (Automatic Meter Reading), yaitu sistem membaca atau mengambil data dari pengukuran energi listrik pada konsumen secara lokal dan jarak jauh, dimana jadwal membaca dapat ditentukan sebagai dibutuhkan. Sistem AMR ini dapat digunakan secara optimal untuk penerbitan akun, analisis beban pelanggan, perhitungan kehilangan atau kehilangan distribusi, perencanaan pengembangan jaringan listrik.

Menurut hasil wawancara dengan salah satu karyawan di sektor Distribusi PT. PLN (Persero) Distribusi Jakarta Raya, sistem AMR (Automatic Meter Reading) yang telah diterapkan dapat mendeteksi kerugian (kerugian daya listrik) baik Teknis maupun Non-Teknis. Saat ini untuk mendeteksi kerugian itu sendiri masih diperiksa langsung dengan membaca dan memeriksa setiap data pelanggan yang masuk.

Salah satu masalah yang dihadapi oleh PLN adalah penyusutan non-teknis yang tinggi dari calon pelanggan AMR karena kesalahan pemasangan dan pemeliharaan serta salah satu penyumbang kerugian besar adalah tindakan penipuan yang dilakukan oleh beberapa konsumen. Metode penelitian yang digunakan dalam penelitian ini adalah pendekatan kualitatif menggunakan Metode Studi Kasus, yang menganalisis dan menghitung secara langsung [2] [3] [8] [11] [20]. Penyebab hilangnya energi yang dapat diidentifikasi melalui analisis data AMR meliputi; kesalahan pembacaan meter, kelainan pengukuran dan kesalahan selama pemasangan kabel, yang merupakan kesalahan berdasarkan kerugian non-teknis [3] [8] [11].

Analisis data dan evaluasi penggunaan energi menggunakan data unduhan pelanggan AMR yang dimiliki oleh PT. PLN (Persero) Distribusi Jakarta Raya. Data akan diproses dan dikelompokkan berdasarkan pola penggunaan kekuatannya. Penelitian ini menggunakan metode $K$ Means Clustering Data Mining. Metode K-Means adalah algoritma clustering tertua dan paling banyak digunakan dalam berbagai aplikasi kecil hingga menengah karena kemudahan implementasi dan kompleksitas waktu yang cepat. [4] [8] [9] [10] [11] [12]. Selain itu K-Means juga memiliki akurasi yang cukup tinggi pada ukuran objek, sehingga algoritma ini relatif lebih terukur dan efisien untuk memproses sejumlah besar objek [5]. Kelemahan dalam algoritma K-Means adalah menganalisis dan menentukan jumlah terbaik K dalam pengelompokan data dalam dataset [6] [14] [15] [16] [17] [18]. Untuk mendapatkan nilai K optimal, penulis menggunakan metode DaviesBouldin Index (DBI). Indeks Davies-Bouldin mengukur kesamaan rata-rata antara setiap klaster dan salah satu yang paling mirip. Nilai Indeks DB minimum adalah skema pengelompokan yang paling optimal [7].

Diharapkan bahwa hasil clustering pada data historis penggunaan daya listrik pelanggan AMR PT. PLN (Persero) Distribusi Jakarta Raya dengan metode K-Means menghasilkan hasil cluster yang optimal untuk menemukan sekelompok pola penggunaan daya pelanggan, sehingga dapat digunakan sebagai referensi dalam menganalisis setiap grafik penggunaan dari data historis tentang listrik pelanggan penggunaan daya dan mendeteksi kerugian non-teknis dari pelanggan.atau hilangnya daya listrik dalam sistem distribusi tenaga listrik yang biasanya digunakan pada waktu-waktu tertentu, adalah salah satu ukuran yang efisien atau tidak pada operasi sistem tenaga listrik [1][2] [3] [10] [12] [19].

Saat ini telah diterapkan metode pengukuran energi listrik menggunakan AMR (Automatic Meter Reading) sistem, yaitu, sistem membaca atau mengambil data dari pengukuran energi listrik 
pada konsumen lokal dan jarak jauh, dimana jadwal bacaan dapat ditentukan sesuai kebutuhan. Sistem AMR ini dapat digunakan secara optimal untuk pengeluaran akun, analisa beban konsumen, perhitungan kerugian atau kerugian distribusi, perencanaan pembangunan jaringan listrik.

Menurut hasil wawancara dengan salah satu karyawan di sektor distribusi PT. PLN (Persero) distribusi Jakarta Raya, sistem AMR (Automatic Meter Reading) yang telah diaplikasikan ini dapat mendeteksi kerugian (kehilangan daya listrik) baik teknis maupun non-teknis. Saat ini untuk mendeteksi kerugian itu sendiri masih diperiksa langsung dengan membaca dan memeriksa setiap data pelanggan yang masuk.

Salah satu masalah yang dihadapi PLN adalah tingginya penyusutan non-teknis dari potensi pelanggan AMR karena instalasi yang salah dan pemeliharaan serta salah satu kontributor untuk kerugian tinggi adalah tindakan curang yang dilakukan oleh beberapa konsumen. Metode penelitian yang digunakan dalam studi ini adalah pendekatan kualitatif menggunakan metode studi kasus, yang menganalisa dan menghitung secara langsung [2][3] [8] [11] [20]. Penyebab kerugian energi yang dapat diidentifikasi melalui analisis data AMR meliputi; kesalahan pembacaan meter, kelainan pengukuran dan kesalahan selama pengkabelan, yang merupakan kesalahan berdasarkan kerugian non-teknis [3][8] [11].

Analisis data dan evaluasi penggunaan energi menggunakan data download pelanggan AMR milik PT. PLN (Persero) distribusi Jakarta Raya. Data akan diproses dan dikelompokkan berdasarkan pola penggunaan kekuatannya. Kajian ini menggunakan metode $\mathrm{K}$ Means Clustering Data Mining. Metode K-Means adalah algoritma clustering tertua dan paling banyak digunakan dalam berbagai aplikasi kecil hingga sedang karena kemudahan implementasi dan kompleksitas waktu yang cepat. [4] [8] [9] [10] [11] [12]. Selain itu K-Means juga memiliki akurasi yang cukup tinggi pada ukuran objek, sehingga algoritma ini relatif lebih terukur dan efisien untuk memproses sejumlah besar benda [5]. Kelemahan dalam algoritma $K$-Means adalah menganalisis dan menentukan jumlah terbaik K dalam pengelompokan data dalam dataset [6] [14] [15] [16] [17] [18]. Untuk mendapatkan nilai K yang optimal, penulis menggunakan metode Davies-Bouldin Index (DBI). Indeks DaviesBouldin mengukur kesama rataan antara setiap kelompok dan salah satu yang paling mirip. Nilai minimum DB Index adalah skema Clustering paling optimal [7].

Diharapkan hasil pengelompokan data historis penggunaan daya listrik nasabah AMR PT. PLN (Persero ) distribusi Jakarta Raya dengan metode K-means menghasilkan hasil cluster optimal untuk menemukan sekumpulan pola penggunaan daya pelanggan, sehingga dapat digunakan sebagai acuan dalam menganalisa setiap graf penggunaan dari data historis pada penggunaan daya listrik pelanggan dan mendeteksi kerugian non-teknis dari pelanggan.

\section{METODE PENELITIAN}

Penelitian yang telah dilakukan sebelumnya terkait dengan PT. PLN pada tahun 2017 dengan judul penelitian "Pengembangan Model Kelistrikan Berbasis Masyarakat Multimedia" dan pada tahun 2019 dengan tema penelitian tentang pemrosesan data historis pelanggan PT. PLN untuk memantau data pelanggan Pasca Bayar, terutama data pelanggan yang menunggak untuk mempermudah petugas lapangan dalam proses pemasangan listrik baru atau dalam proses penagihan untuk pelanggan yang menunggak selama satu bulan, dua, atau tiga bulan menunggak.

Penelitian berikutnya pada tahun yang sama tahun 2019 adalah tentang pelanggan listrik PLN AMR, untuk Klasterisasi Otomasi Pelanggan Pemanfaatan Tenaga Historis untuk Mendeteksi kehilangan daya dalam Upaya Meningkatkan Efisiensi Konsumsi Energi Listrik.

Data yang digunakan dalam penelitian ini adalah data historis penggunaan daya pelanggan AMR (Automatic Meter Reading), tarif listrik untuk keperluan bisnis, 'tarif B-3 atau Tegangan 
Menengah (batas daya di atas 200kVA) di PT. PLN (Persero) Distribusi Jakarta Raya. Sedangkan atribut yang akan digunakan adalah Power berdasarkan Waktu Beban Puncak (WBP, jam 18:00 22:00) dan Daya berdasarkan Waktu Beban Puncak Luar (LWBP, 22:00 - 18:00) selama 7 hari.

A. Pelatihan data digunakan oleh 103 pelanggan yang termasuk pelanggan dengan penggunaan daya listrik normal.

B. Pengujian data digunakan oleh 3 pelanggan yang diklasifikasikan sebagai penggunaan tenaga listrik yang tidak normal (Kerugian non-teknis).

Metode penelitian adalah:
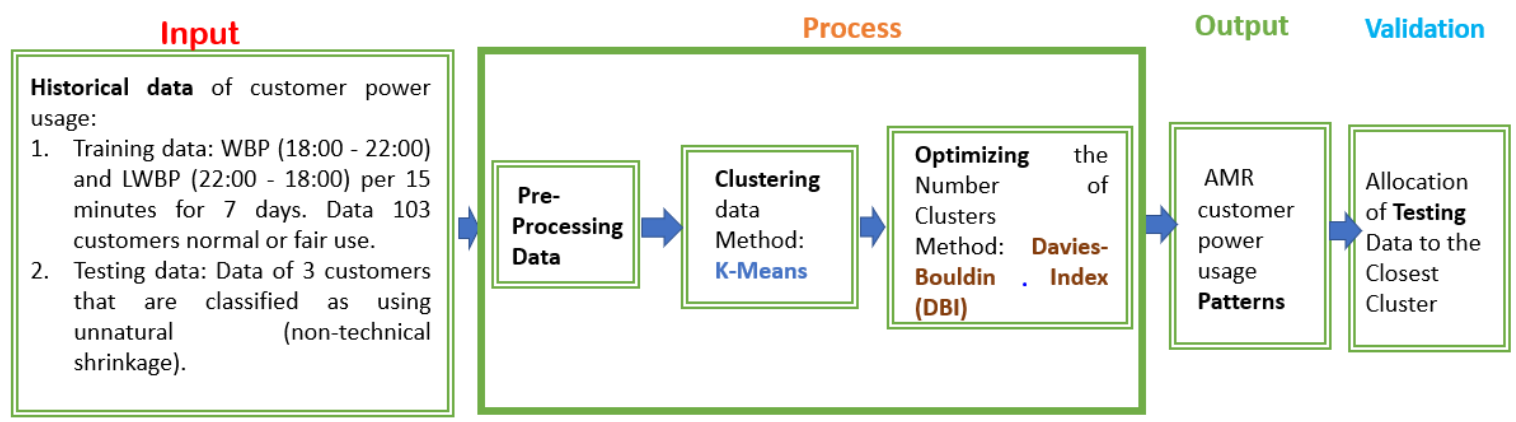

Gambar 1. Metode Penelitian

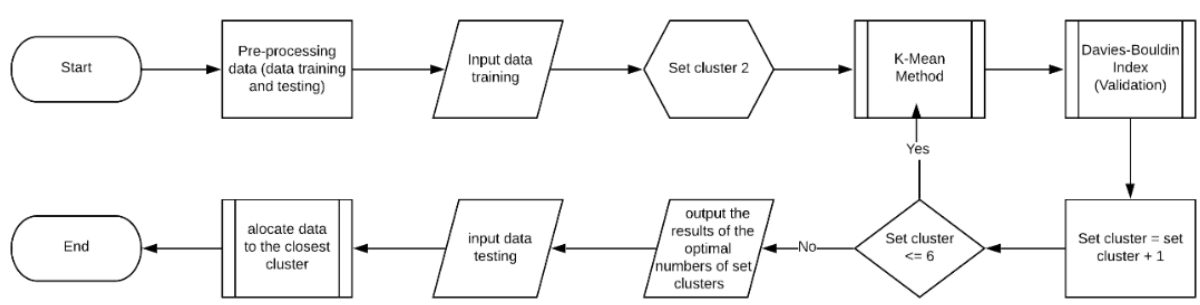

Gambar 2. Proses Desain

Tahap ini adalah pekerjaan mayoritas dalam penambangan data. Dimana tahap ini adalah proses memahami data dan pengolahan data awal yang nantinya akan digunakan dalam proses perhitungan dengan metode yang telah ditentukan. Data yang akan diproses adalah data profil beban pada penggunaan daya dari setiap pelanggan AMR untuk pelanggan bisnis dari kelompok tarif B3 / TM. Penulis mengambil 5 (lima) sampel data yang telah melewati tahap pra-pemrosesan untuk digunakan sebagai contoh dalam proses perhitungan.

Selanjutnya adalah perhitungan menggunakan metode K-Means untuk menentukan pola grup kelas bisnis penggunaan daya pelanggan AMR (Automatic Meter Reading). Tahapan perhitungan akan dijelaskan berdasarkan proses diagram alur di bawah ini:

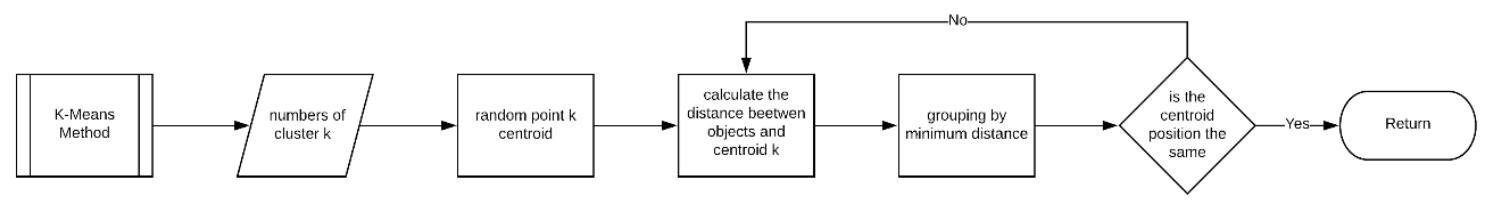

Gambar 3. Proses K-Means

Berikut ini adalah contoh proses perhitungan untuk pengelompokan centroid, langsung ke tahap iterasi terakhir, data dapat dilihat pada tabel 1. 
Table 1. Centroid set 2 cluster final

\begin{tabular}{cccccccc} 
& $\mathrm{A}$ & $\mathrm{B}$ & $\mathrm{C}$ & $\mathrm{D}$ & $\mathrm{E}$ & $\mathrm{F}$ & $\mathrm{G}$ \\
\hline $\mathrm{C} 1$ & 0,266 & 0,250 & 0,284 & 0,252 & 0,279 & 0,247 & 0,273 \\
$\mathrm{C} 2$ & 0,630 & 0,476 & 1,213 & 1,220 & 1,244 & 1,250 & 1,151 \\
\hline & $\mathrm{H}$ & $\mathrm{I}$ & $\mathrm{J}$ & $\mathrm{K}$ & $\mathrm{L}$ & $\mathrm{M}$ & $\mathrm{N}$ \\
\hline $\mathrm{C} 1$ & 0,247 & 0,276 & 0,246 & 0,267 & 0,247 & 0,266 & 0,255 \\
$\mathrm{C} 2$ & 1,249 & 1,227 & 1,231 & 1,197 & 1,304 & 0,635 & 0,808 \\
\hline
\end{tabular}

Setelah melakukan perhitungan K-Means dan mendapatkan pengelompokan centroid, berikut ini adalah contoh data yang akan diuji.

Table 2. Examples of Data Testing

\begin{tabular}{cccccccc}
\hline Customer & $\mathrm{A}$ & $\mathrm{B}$ & $\mathrm{C}$ & $\mathrm{D}$ & $\mathrm{E}$ & $\mathrm{F}$ & $\mathrm{G}$ \\
\hline 1 & 0,374 & 0,342 & 0,398 & 0,347 & 0,402 & 0,347 & 0,391 \\
\hline Customer & $\mathrm{H}$ & $\mathrm{I}$ & $\mathrm{J}$ & $\mathrm{K}$ & $\mathrm{L}$ & $\mathrm{M}$ & $\mathrm{N}$ \\
\hline 1 & 0,344 & 0,400 & 0,352 & 0,390 & 0,352 & 0,376 & 0,363 \\
\hline
\end{tabular}

Hitung nilai jarak maksimum (maks. DC) di setiap kluster yang terbentuk (Misalnya, himpunan klaster optimal $=2$, berdasarkan tahap sebelumnya)

Table 3. Maximum DC in each cluster

\begin{tabular}{ccc}
\hline Customer & DC1 & DC2 \\
\hline 1 & 0,418 & \\
2 & 0,148 & \\
3 & 0,292 & \\
4 & & 0 \\
5 & 0,273 & \\
\hline MAX DC & $\mathbf{0 , 4 1 8}$ & $\mathbf{0}$ \\
\hline
\end{tabular}

Hitung DC dari setiap objek data pelatihan ke centroid, menggunakan rumus Euclidean:

\begin{tabular}{cc}
\multicolumn{2}{r}{ Table 4. DC value } \\
\hline DC1 & DC2 \\
\hline 0,409 & 2,776 \\
\hline
\end{tabular}

Bandingkan nilai pengujian data DC dengan masing-masing maks DC di setiap kluster yang telah dihitung. Hasil banding dapat dikategorikan sebagai berikut:

1. Jika semua data DC menguji <= $\max$ (DC) per cluster, maka data tersebut diklasifikasikan sebagai Normal yang digunakan.

2. Jika salah satu dari DC data testing $>=\max (\mathrm{DC})$ per cluster, maka data tersebut diklasifikasikan sebagai Normal yang digunakan.

3. Jika semua pengujian data $\mathrm{DC}>=\max (\mathrm{DC})$ per cluster, maka data tersebut diklasifikasikan sebagai data abnormal yang digunakan.

Pengujian DC1: Pelatihan DC1 = 0,409<0,418,

Pengujian DC2: Pelatihan DC2 $=2,776>0$,

Berdasarkan hasil perbandingan di atas, dapat disimpulkan, bahwa Pengujian Data diklasifikasikan sebagai Data Normal dalam penggunaan daya. Dari proses perhitungan yang dijelaskan di atas, sampel yang digunakan adalah pelanggan Kelas Bisnis 5 AMR (B-3) dengan mengelompokkan menggunakan cluster set 2 dan menggunakan 14 atribut di mana 14 atribut dibagi menjadi 2, 7 di antaranya adalah data penggunaan daya LWBP untuk 77 hari dan lagi adalah data penggunaan daya WBP selama 7 hari, dalam perhitungannya mendapatkan hasil, yaitu :

1. Ada 2 pola yang terbentuk dari hasil 5 pengelompokan data pelanggan. Pola penggunaan daya terbentuk dari nilai centroid akhir yang diperoleh setelah hasil iterasi berakhir. 
2. Di cluster pertama ada 4 pelanggan, sedangkan untuk cluster kedua hanya ada 1 pelanggan. Artinya, dari lima pelanggan ada 4 pelanggan yang memiliki kesamaan dalam pola penggunaan daya dan 1 pelanggan lainnya memiliki pola yang berbeda dari 4 pelanggan.

3. Untuk level optimal dari kumpulan 2 klaster untuk 5 pelanggan berdasarkan perhitungan diperoleh nilai 0,095 berdasarkan perhitungan menggunakan rumus Indeks DaviesBouldin.

Setelah pola diperoleh, tes pengujian dilakukan untuk kemudian membuat perbandingan apakah data pengujian dimasukkan atau dibentuk seperti pola yang diperoleh atau tidak. Jika hasil data pengujian tidak memiliki kesamaan dengan pola, dalam hal ini jarak ke pusat massa setiap kluster yang diperoleh melebihi jarak maksimum anggota dalam kluster, maka data pengujian pelanggan tidak adil dalam penggunaan tenaga listrik dan ditetapkan sebagai target operasi.

\section{HASIL DAN PEMBAHASAN}

Dalam studi ini, data profil muatan daya tidak dikelompokkan berdasarkan kriteria tertentu, tetapi dikelompokkan secara umum didasarkan pada pola penggunaan daya. Karena jumlah cluster yang akan digunakan tidak diketahui, penulis memutuskan untuk menggunakan beberapa cluster untuk metode K-Means pengelompokan tes. Set cluster yang digunakan adalah dari 2 cluster set untuk 6 cluster set. Setelah menghitung menggunakan metode K-Means, tingkat optimasi masingmasing cluster kemudian dihitung menggunakan metode Davies-Bouldin Index (DBI). Berikut adalah hasil penghitungan pada iterasi terakhir:

Table 4.1 The number of members of each iteration set cluster 6

\begin{tabular}{cc}
\hline Iteration & Number of Members \\
\hline 1 & Cluster 1: 5 Member \\
& Cluster 2: 55 Member \\
& Cluster 3: 31 Member \\
& Cluster 4: 2 Member \\
& Cluster 5: 9 Member \\
& Cluster 6: 1 Member \\
& Cluster 1: 4 Member \\
2 & Cluster 2: 51 Member \\
& Cluster 3: 35 Member \\
& Cluster 4: 1 Member \\
& Cluster 5: 10 Member \\
& Cluster 6: 2 Member \\
\hline
\end{tabular}

Table 5. The end centroid value of cluster 1 in cluster set 6

\begin{tabular}{ccccccc}
\hline $\mathrm{A}$ & $\mathrm{B}$ & $\mathrm{C}$ & $\mathrm{D}$ & $\mathrm{E}$ & $\mathrm{F}$ & $\mathrm{G}$ \\
\hline 0,407 & 0,493 & 0,548 & 0,439 & 0,513 & 0,491 & 0,479 \\
\hline $\mathrm{H}$ & $\mathrm{I}$ & $\mathrm{J}$ & $\mathrm{K}$ & $\mathrm{L}$ & $\mathrm{M}$ & $\mathrm{N}$ \\
\hline 0,418 & 0,538 & 0,433 & 0,399 & 0,373 & 0,267 & 0,288 \\
\hline
\end{tabular}

Table 6. The end centroid value of cluster 2 in cluster set 6

\begin{tabular}{ccccccc}
\hline A & B & C & D & E & F & G \\
\hline 0,062 & 0,064 & 0,076 & 0,104 & 0,075 & 0,111 & 0,074 \\
\hline H & I & J & K & L & M & N \\
\hline 0,108 & 0,074 & 0,109 & 0,081 & 0,112 & 0,072 & 0,068 \\
\hline
\end{tabular}


PETIR: Jurnal Pengkajian dan Penerapan Teknik Informatika

Vol. 13, No. 2, September 2020, P-ISSN 1978-9262, E-ISSN 2655-5018

DOI: https://doi.org/10.33322/petir.v13i2.1067

Table 7. The end centroid value of cluster 3 in cluster set 6

\begin{tabular}{ccccccc}
\hline A & B & C & D & E & F & G \\
\hline 0,155 & 0,148 & 0,188 & 0,197 & 0,19 & 0,203 & 0,188 \\
\hline H & I & J & K & L & M & N \\
\hline 0,202 & 0,191 & 0,202 & 0,191 & 0,206 & 0,167 & 0,156 \\
\hline
\end{tabular}

Table 8. The end centroid value of cluster 4 in cluster set 6

\begin{tabular}{ccccccc}
\hline A & B & C & D & E & F & G \\
\hline 0,641 & 0,788 & 1,608 & 1,329 & 1,635 & 1,558 & 1,690 \\
\hline $\mathrm{H}$ & $\mathrm{I}$ & $\mathrm{J}$ & $\mathrm{K}$ & $\mathrm{L}$ & $\mathrm{M}$ & $\mathrm{N}$ \\
\hline 1,633 & 1,653 & 1,671 & 1,729 & 1,640 & 0,719 & 1,351 \\
\hline
\end{tabular}

Table 9. The end centroid value of cluster 5 in cluster set 6

\begin{tabular}{ccccccc}
\hline A & B & C & D & E & F & G \\
\hline 0,333 & 0,274 & 0,348 & 0,277 & 0,35 & 0,279 & 0,337 \\
\hline H & I & J & K & L & M & N \\
\hline 0,277 & 0,348 & 0,276 & 0,332 & 0,283 & 0,328 & 0,293 \\
\hline
\end{tabular}

Table 10. The end centroid value of cluster 6 in cluster set 6

\begin{tabular}{ccccccc}
\hline $\mathrm{A}$ & $\mathrm{B}$ & $\mathrm{C}$ & $\mathrm{D}$ & $\mathrm{E}$ & $\mathrm{F}$ & $\mathrm{G}$ \\
\hline 0,359 & 0,480 & 1,043 & 1,125 & 1,045 & 1,219 & 1,020 \\
\hline $\mathrm{H}$ & $\mathrm{I}$ & $\mathrm{J}$ & $\mathrm{K}$ & $\mathrm{L}$ & $\mathrm{M}$ & $\mathrm{N}$ \\
\hline 1,200 & 1,050 & 1,200 & 1,034 & 1,269 & 0,434 & 0,646 \\
\hline
\end{tabular}

Table 11. The results of the DBI value calculation for each set of clusters

\begin{tabular}{|c|c|c|}
\hline Set Cluster & DBI & Number of Members \\
\hline 2 & 1.234 & $\begin{array}{l}\text { Cluster 1: } 15 \\
\text { Cluster 2: } 88\end{array}$ \\
\hline 3 & 0.931 & $\begin{array}{l}\text { Cluster 1: } 4 \\
\text { Cluster 2: } 58 \\
\text { Cluster 3: } 41\end{array}$ \\
\hline 4 & 0.893 & $\begin{array}{l}\text { Cluster 1: } 12 \\
\text { Cluster 2: } 54 \\
\text { Cluster 3: } 34 \\
\text { Cluster 4: } 3\end{array}$ \\
\hline 5 & 1.174 & $\begin{array}{l}\text { Cluster 1: } 4 \\
\text { Cluster 2: } 51 \\
\text { Cluster 3: } 35 \\
\text { Cluster 4: } 3 \\
\text { Cluster 5: } 40\end{array}$ \\
\hline 6 & 0.990 & $\begin{array}{l}\text { Cluster 1: } 4 \\
\text { Cluster 2: } 51 \\
\text { Cluster 3: } 35 \\
\text { Cluster 4: } 1 \\
\text { Cluster 5: } 10 \\
\text { Cluster 6: } 2\end{array}$ \\
\hline
\end{tabular}

Berdasarkan hasil perhitungan dalam aplikasi, cluster set yang paling optimal adalah set cluster 4 karena memiliki nilai DBI terkecil, yaitu, 0,893, yang berarti set cluster 4 memiliki kepadatan masing-masing objek dengan centroid terbaik dan jarak antara cluster juga dipisahkan dengan baik.

Karena himpunan cluster ke-4 memiliki kinerja terbaik dalam pengelompokan data sejarah penggunaan daya dari AMR (Automatic meter membaca) pelanggan di kelas bisnis, masing-masing 
PETIR: Jurnal Pengkajian dan Penerapan Teknik Informatika

Vol. 13, No. 2, September 2020, P-ISSN 1978-9262, E-ISSN 2655-5018

DOI: https://doi.org/10.33322/petir.v13i2.1067

centroid atau titik pusat setiap cluster digunakan sebagai atribut dan nilai dari grafik bisnis penggunaan daya AMR pelanggan di PT. PLN (Persero) distribusi Jakarta Raya.

Setelah mendapatkan kumpulan cluster yang optimal, maka fase pengujian. Pada langkah ini data yang diuji adalah data 3 pelanggan yang dikategorikan sebagai pelanggan dengan daya listrik penggunaan tidak normal. Pengujiannya adalah, dengan menentukan jarak masing-masing objek pengujian data ke setiap centroid di cluster 4 set maka 3 data diuji dengan output yaitu, data ke-3 tidak normal dalam penggunaan daya listrik. Pengujiannya adalah, dengan menentukan jarak dari masing-masing objek pengujian data ke setiap centroid di cluster 4 set maka 3 data diuji dengan output yaitu, ketiga data tersebut diklasifikasikan menjadi pelanggan dengan penggunaan yang tidak wajar karena berdasarkan pada proses alokasi data untuk centroid mengatur cluster terdekat 4 , jarak data pengujian melebihi jarak maksimum setiap objek di setiap cluster dalam kumpulan cluster 3 .

Dapat dilihat perbandingan penggunaan energi listrik normal dan tidak normal berdasarkan perbandingan bentuk grafik antara Gambar 4. dan Gambar 5. Pola penggunaan energi pada Gambar 5. tidak memiliki pola yang sama atau sesuai dengan masing-masing pola pada Gambar 4.

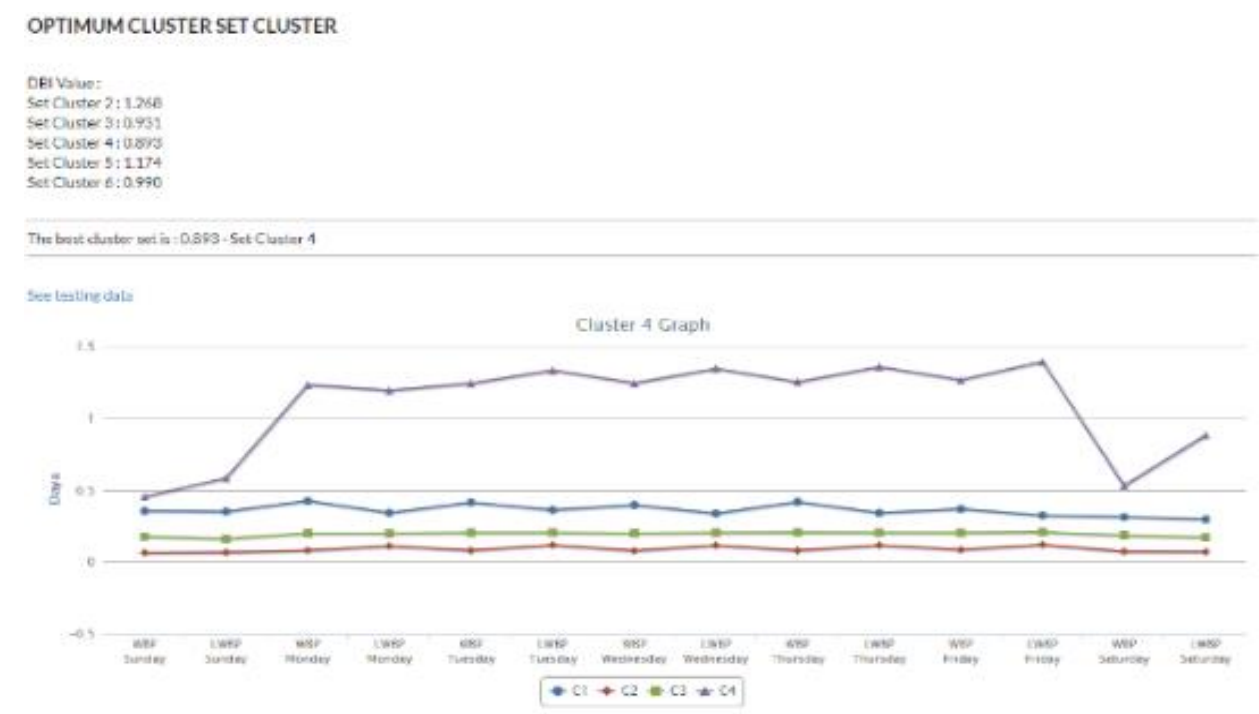

Gambar 4. Diagram Kelompok Pola Daya Pengguna Kelas Pelanggan AMR

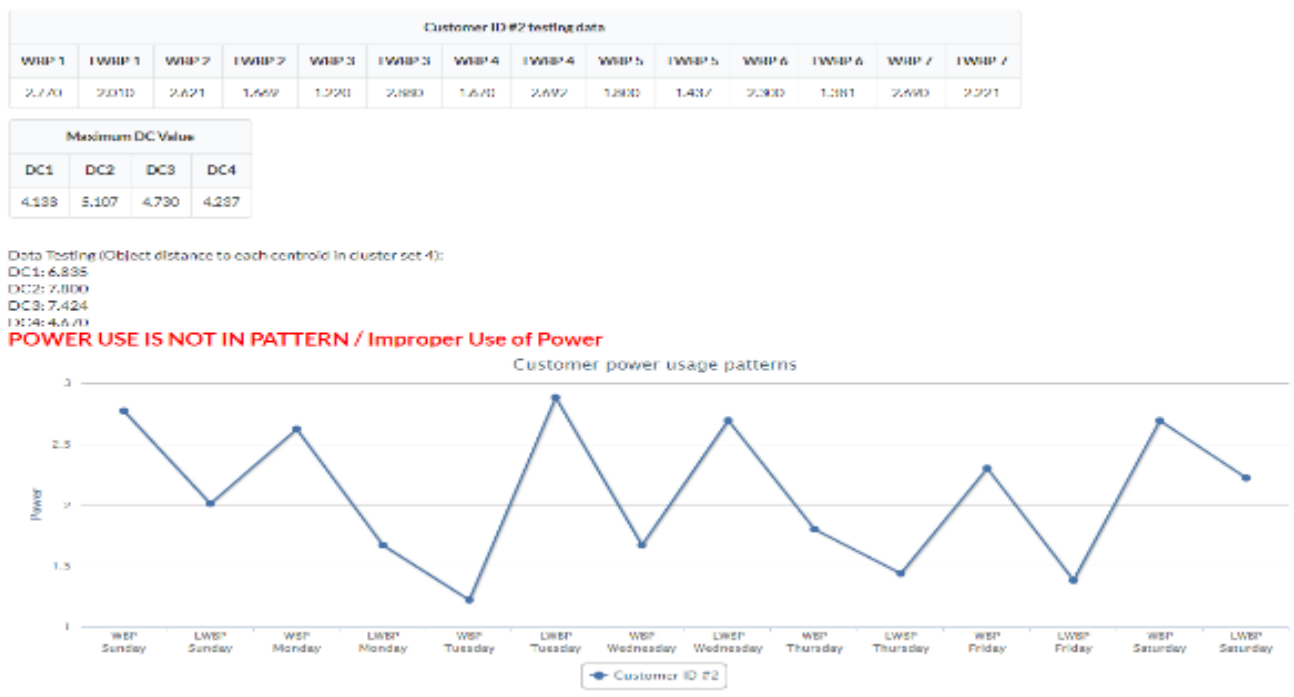

Gambar 5. Grafik Konsumsi Energi Pelanggan Tidak Normal 
PETIR: Jurnal Pengkajian dan Penerapan Teknik Informatika

Vol. 13, No. 2, September 2020, P-ISSN 1978-9262, E-ISSN 2655-5018 DOI: https://doi.org/10.33322/petir.v13i2.1067

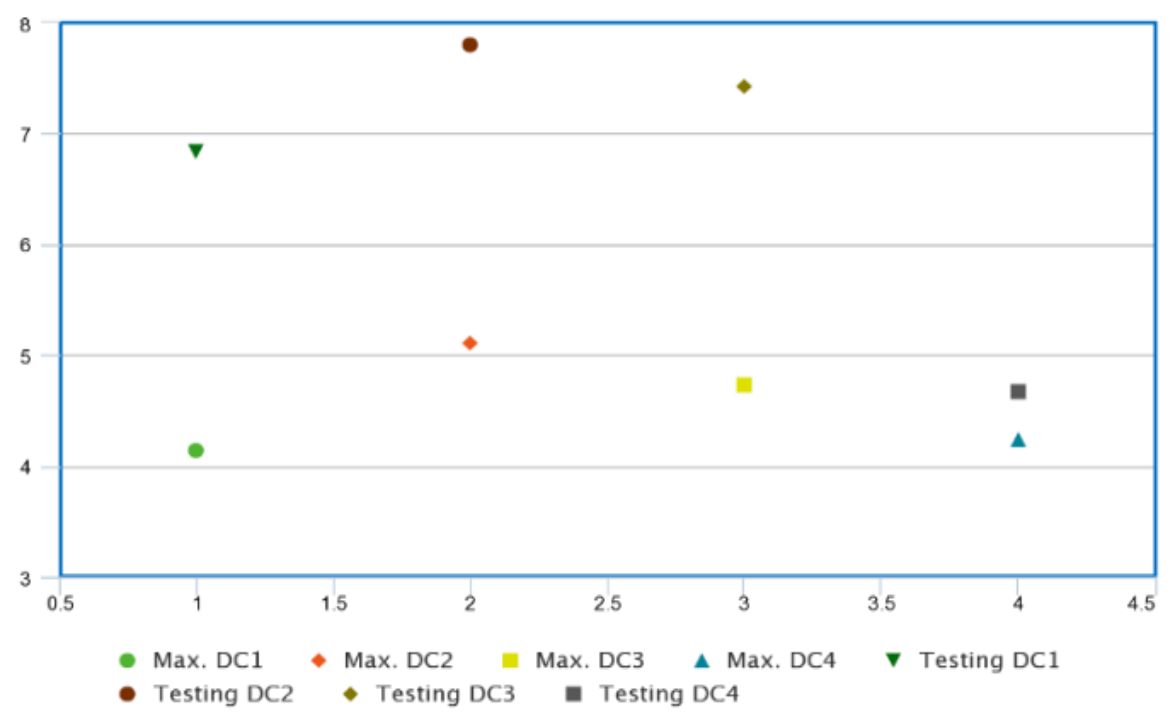

Gambar 6. Diagram Sebaran Plot Data Pengujian Konsumen

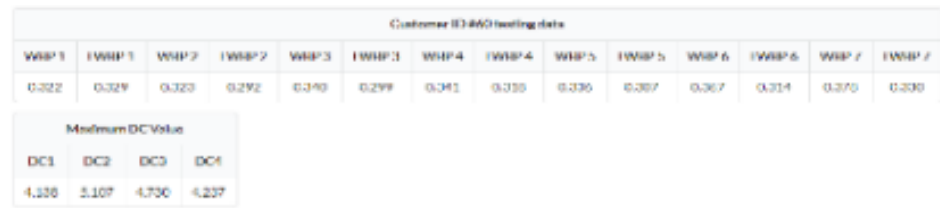

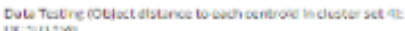

ix: $\operatorname{sintw}$
Des 20.910

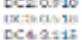

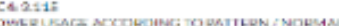

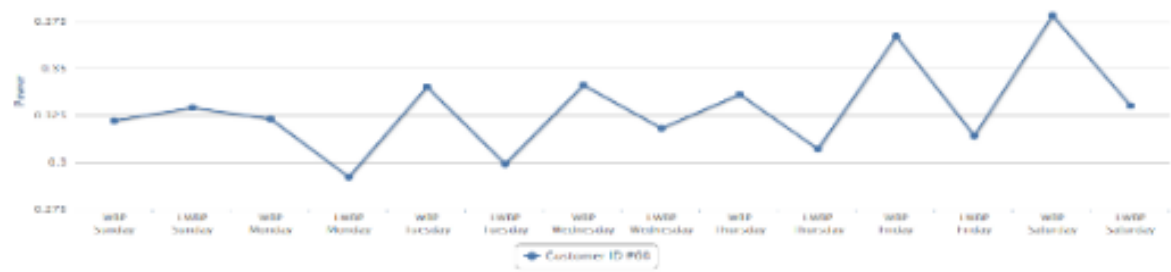

Gambar 7. Pola Penggunaan Daya Pelanggan Normal

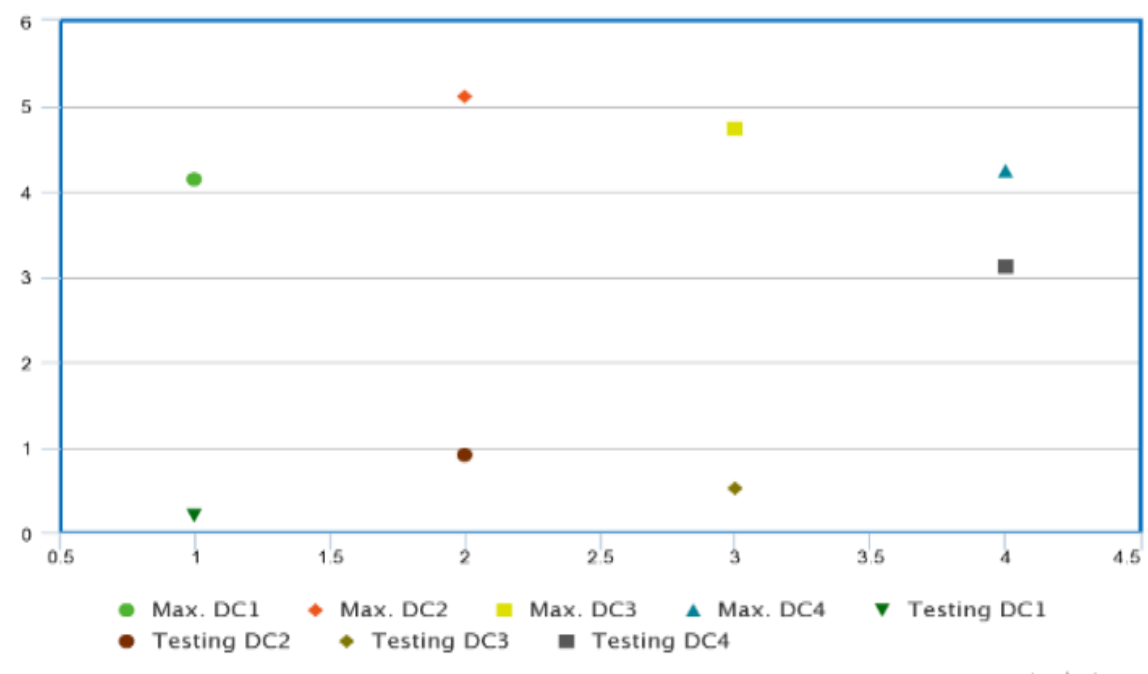

Gambar 8. Scatter Plot Diagram of Consumer Testing Data 
Pelanggan yang dikatakan tidak cocok dengan pola atau tidak masuk ke dalam cluster apa pun, dapat dilihat pada nilai DC dari setiap pelanggan, yang juga telah menentukan nilai DC maksimum untuk setiap pola, jika nilai DC pelanggan melebihi nilai DC maksimum, maka dapat dikatakan bahwa pelanggan tidak sesuai pola yang telah ditentukan. Selain melihat nilai DC dari setiap pelanggan, itu juga dapat dibandingkan antara nilai WBP dan LWBP di setiap cluster dan nilai WBP dan LWBP untuk setiap pelanggan. Nilai tertinggi minggu WBP di setiap cluster, memiliki nilai tertinggi 0,453 di cluster 4, sedangkan untuk pelanggan, nilai WBP minggu adalah 2,770, yang telah melewati nilai tertinggi dari setiap cluster.

\section{KESIMPULAN DAN SARAN}

Berdasarkan uraian pembahasan di atas, Pengelompokan data historis tentang penggunaan daya pelanggan kelas bisnis AMR (Automatic Meter Reading) PT. PLN (Persero) Distribusi Jakarta Raya telah berhasil dibangun dan dapat digunakan untuk mengklasifikasikan dan menentukan pola penggunaan tenaga listrik berdasarkan jumlah set cluster yang telah dihitung untuk optimasi mereka. Berdasarkan hasil pengujian dengan 2-6 set cluster, hasil cluster set adalah yang paling optimal yaitu pada set 4 cluster karena memiliki nilai DBI terkecil (minimum), 0,893. Dimana di set 4 cluster, cluster 1 memiliki 12 anggota, cluster 2: 54 anggota, anggota cluster 3: 34 dan cluster 4: 3 anggota. Ada 4 pola penggunaan daya listrik pelanggan AMR (Automatic Meter Reading) pelanggan kelas bisnis (B-3 atau kelas tegangan menengah, batas daya di atas 200kVA).

Pelanggan yang dikatakan tidak cocok dengan pola atau tidak masuk ke dalam cluster apa pun, dapat dilihat pada nilai DC dari setiap pelanggan, yang juga telah menentukan nilai DC maksimum untuk setiap pola, jika nilai DC pelanggan melebihi nilai DC maksimum, maka dapat dikatakan bahwa pelanggan tidak sesuai pola yang telah ditentukan. Selain melihat nilai DC dari setiap pelanggan, itu juga dapat dibandingkan antara nilai WBP dan LWBP di setiap cluster dan nilai WBP dan LWBP untuk setiap pelanggan. Nilai tertinggi minggu WBP di setiap cluster, memiliki nilai tertinggi 0,453 di cluster 4 , sedangkan untuk pelanggan, nilai WBP minggu adalah 2,770, yang telah melewati nilai tertinggi dari setiap cluster.

\section{UCAPAN TERIMAKASIH}

Terimakasih yang sebesar-besarnya kami ucapkan kepada Lembaga Penelitian Pengabdian Masyarakat (LPPM) Institut Teknologi PLN yang telah membiayai Penelitian Unggulan Departemen Tahun Anggaran 2019 dengan Nomor Kontrak 009/1/A01/PUD-II/STT-PLN/2019 Tanggal 19 Desember 2019.

\section{DAFTAR PUSTAKA}

[1] S. S. Bhatti, E. M. Umair, U. Lodhi, and S. Haq, "Electric-Power-Transmission-andDistribution-Losses-Overview-and-Minimization-in-Pakistan.docx,” Int. J. Sci. Eng. Res., 2015.

[2] B. Pradana, P. Purba, and E. Warman, "Pendekatan Kurva Beban Pada Jaringan Distribusi PT . PLN ( Persero ) Rayon Medan Kota," Singuda Ensikom, vol. 6, no. 2, pp. 60-64, 2014.

[3] P. A. Yuntyansyah, U. Wibawa, and T. Utomo, "Studi Perkiraan Susut Teknis dan Alternatif Perbaikan Pada Penyulang Kayoman Gardu Induk Sukorejo," pp. 1-8, 2015.

[4] J. Suryanto, "Analisa Perbandingan Pengelompokkan Curah Hujan 15 Harian Provinsi Diy Menggunakan Fuzzy Clustering Dan K-Means Clustering,” J. AGRIFOR, vol. XVI, pp. 229242, 2017.

[5] S. Ghosh and S. Kumar, "Comparative Analysis of K-Means and Fuzzy C-Means 
Algorithms,” Int. J. Adv. Comput. Sci. Appl., 2013, doi: 10.14569/ijacsa.2013.040406.

[6] A. T. Rahman, Wiranto, and A. Rini, "Coal Trade Data Clustering Using K-Means (Case Study Pt. Global Bangkit Utama)," ITSMART J. Teknol. dan Inf., 2017, doi: 10.20961/ITS.V6I1.11296.

[7] E. Kuswantoro and Y. K. Suprapto, "Penerapan Algoritma K-MeansDengan Optimasi Jumlah Cluster Untuk Pengelompokan Angkatan Kerja Propinsi Jatim,” JAVA J. Electr. Electron. Eng., 2015.

[8] A. Muhammad, H. Tumaliang, and S. Silimang, "Analisa Rugi-Rugi Energi Listrik Pada Jaringan Distribusi (JTM) Di PT. PLN (Persero) Area Gorontalo,” Anal. Rugi-Rugi Energi List. Pada Jar. Distrib. Di PT. PLN Area Gorontalo, 2019, doi: 10.35793/jtek.7.3.2018.23634.

[9] F. E. Nasution and J. M. T, "Pengaruh Faktor Daya Customer Industri Terhadap Rugi - Rugi Pada Jaringan Sisi Sekunder Transformator Distribusi Pt . Pln ( Persero ) Area Serpong," Semin. Nas. Teknol. Fak. Tek. Univ. Krisnadwipayana, 2019.

[10] A. Heriyanto, "Studi Kasus Kinerja AMR (Automatic Meter Reading) Pada Customer Potensial Daya 41.5 KVA - 200 KVA Di Situbondo,” J. Tek. Elektro Univ. Muhammadiyah Jember, 2016.

[11] J. Mangundap, Silimang, Sartje, and H. Tumaliang, "Analisa Rugi-Rugi Daya Jaringan Distribusi Di PT. PLN (Persero) Area Manado 2017,” J. Tek. Elektro dan Komput., 2018.

[12] E. Agustina and A. F. Amalia, "Penurunan Susut Non Teknis Pada Jaringan Distribusi Menggunakan Sistem Automatic Meter Reading Di Pt. Pln (Persero)," J. Tek. Mesin, 2017, doi: $10.22441 /$ jtm.v5i4.1223.

[13] M. Samarth Pandit, M. Snehamandhre, and M. Meghananichal, "Smart Energy Meter using internet of Things (IoT),” J. Eng. Res. www.vjer.in, vol. 1, no. 2, pp. 222-229, 2017.

[14] Ediyanto, M. N. Mara, and N. Satyahadewi, "Pengklasifikasian Karakteristik Dengan Metod K-Means Cluster Analysis,” Bul. Ilm., 2013.

[15] Suyanto, "Data mining Untuk Klasifikasi dan Klasterisasi Data," SpringerReference, 2017, doi: 10.1007/SpringerReference_5414.

[16] J. Wu, "Advances in K-means Clustering," Adv. K-means Clust. A Data Min. Think., 2012, doi: 10.1007/978-3-642-29807-3.

[17] D. L. Davies and D. W. Bouldin, "A Cluster Separation Measure,” IEEE Trans. Pattern Anal. Mach. Intell., 1979, doi: 10.1109/TPAMI.1979.4766909.

[18] N. Putu, E. Merliana, and A. J. Santoso, "Analisa Penentuan Jumlah Cluster Terbaik pada Metode K-Means," pp. 978-979.

[19] Agustina, E., \& Amalia, A. F. (2017). Penurunan Susut Non Teknis Pada Jaringan Distribusi Menggunakan Sistem Automatic Meter Reading Di Pt. Pln (Persero). Jurnal Teknik Mesin, 5(4), 37. https://doi.org/10.22441/jtm.v5i4.1223

[20] Rahman, F., Basuki, A., Aknuranda, I., Komputer, F. I., \& Brawijaya, U. (2019). PENGAMBILAN DATA SECARA BERGERAK PADA AUTOMATIC METER Mobile Data Gathering on Automatic Meter Reading with Mesh Network. 6(1), 1-8. https://doi.org/10.25126/jtiik.20196695 